\title{
Study of the ethnic origin of the prothrombin gene (F2) in the admixed Venezuelan population.
}

\author{
Daniela Kansler ${ }^{1}$, Rita Marchi ${ }^{1}$ and Irene Paradisi ${ }^{2}$ \\ ${ }^{1}$ Laboratorio Biología del Desarrollo de la Hemostasia, Instituto Venezolano \\ de Investigaciones Científicas (IVIC), Caracas, Venezuela. \\ ${ }^{2}$ Laboratorio de Genética Humana, Instituto Venezolano de Investigaciones \\ Científicas (IVIC), Caracas, Venezuela.
}

Key words: prothrombin gene (F2); F2 polymorphism $20210 \mathrm{G}>\mathrm{A}$; ethnic origin; rs2070850; rs2070852; rs2282686; rs1799963.

\begin{abstract}
The prothrombin (coagulation factor II), codified by the $F 2$ gene, is the precursor of thrombin that cleaves fibrinogen, leading to a blood clot formation. The $F 2$ mutation $20210 \mathrm{G}>\mathrm{A}\left(\mathrm{c} .{ }^{*} 97 \mathrm{G}>\mathrm{A}\right.$ ) is associated with prothrombin thrombophilia, and carriers have a higher than average risk for developing deep venous thrombosis. The $20210 \mathrm{~A}$ variant is almost absent in populations other than Caucasoid European, and was not found in a Venezuelan population sample of 160 healthy individuals. To assess the possible ethnic origin of the F2 gene in our admixed population, four intragenic SNPs (rs2070850, rs2070852, rs2282686 and rs1799963), with different allelic frequencies according to ethnic groups, were studied and compared with the main 1000 Genomes Project super-populations. The results showed intermediate allelic frequencies in all the SNPs, without differentiating a single specific population, confirming the joint ancestral genetic contribution of the parental populations in Latin America: Spaniards, Africans and Amerindians. Our allelic frequency distribution of the F2 polymorphisms was closer to the AMR (American admixed) subset population of the 1000 Genomes Project. According to this ethnic composition, there is a low probability of detecting carriers of the risk allele 20201A in the Venezuelan healthy general population.
\end{abstract}

\footnotetext{
Corresponding author: Irene Paradisi. Laboratorio de Genética Humana, Centro de Medicina Experimental, Instituto Venezolano de Investigaciones Científicas (IVIC), Altos de Pipe, Km 11 carretera Panamericana, Estado Miranda, Apartado Postal 20632, Caracas 1020-A, Venezuela. Tel.: 58212 5041491; fax: 58212 5041085. E-mail: ireneparadisi@hotmail.com,iparadis@ivic.gob.ve
} 


\section{Origen étnico del gen de la protrombina (F2) en la población venezolana.}

Invest Clin 2019; 60 (4): 269-274

Palabras clave: Gen protrombina (F2); polimorfismo F2 20210 G >A; origen étnico;
rs2070850; rs2070852; rs2282686; rs1799963.

Resumen. La protrombina (factor de coagulación II), codificada por el gen $F 2$, es un precursor de la trombina, la cual escinde al fibrinógeno, conducente a la formación de un coágulo de sangre. La mutación F2 20210 G>A (c. * 97G> A) se asocia con trombofilia y los portadores tienen un riesgo superior al promedio de desarrollar trombosis venosa profunda. La variante 20210 A está casi ausente en poblaciones distintas a la europea caucasoidea, y no se encontró en una muestra de 160 individuos sanos de la población venezolana. Para evaluar el posible origen étnico del gen $F 2$ en nuestra población mezclada, se estudiaron cuatro SNP intragénicos (rs2070850, rs2070852, rs2282686 y rs1799963) con diferentes frecuencias alélicas, según los grupos étnicos y se compararon con las principales superpoblaciones del Proyecto 1000 Genomas. Los resultados mostraron frecuencias alélicas intermedias en todos los SNP, sin diferenciar una única población específica, lo que confirma la contribución genética ancestral conjunta de las poblaciones parentales en América Latina: españoles, africanos y amerindios. Nuestra distribución de frecuencias alélicas de los polimorfismos de $F 2$ fue más parecida al subconjunto AMR (American admixed population) del Proyecto 1000 Genomas. De acuerdo con esta composición étnica, existe una baja probabilidad de detectar portadores del alelo de riesgo 20201A en la población general sana venezolana.

Received: 13-09-2018 Accepted: 09-10-2019

\section{INTRODUCTION}

Prothrombin is a proenzyme that is converted to thrombin by the prothrombinase complex (Factor Xa and Factor Va, assembled on a phospholipidic surface in the presence of $\mathrm{Ca}^{+2}$ ). Thrombin cleaves fibrinogen, which triggers a self-aggregation process that end with clot formation. Approximately, $49 \%$ of prothrombin levels seem to be genetically regulated (1). The prothrombin polymorphisms $20210 \mathrm{G}>\mathrm{A}$ (c. ${ }^{* 97 G>A, ~ r s 1799963) ~(2) ~ a n d ~} 19911$ $\mathrm{A}>\mathrm{G}$ (c.1726-59 A> G, rs3136516) (3) have been associated to increased prothrombin plasma levels, and both represent independent risk factors for venous thrombosis (4-6). The 20210A genetic variant has different prevalence according to the ethnic group, being more frequent in Caucasians, especially Spaniards and Southern Europeans (French, Italians, Greeks) (7-12). We have assessed the prothrombin polymorphism G20210A in a Venezuelan population sample, recruiting 160 healthy subjects from the metropolitan area of Caracas, as described elsewhere (13). All of them were homozygous for the ancestral allele $\mathrm{G}$. 
The allele $\mathrm{A}$ is a worldwide infrequent variant, which is absent in Asian and African populations, and is at very low frequencies in some European populations: Azorian (0.018), Basque (0.020), Spaniards (0.015), Cypriot (0.039), French (0.021) (ALFRED database, https://alfred.med.yale.edu), with a global Minor Allele Frequency (MAF) of 0.0036 (1000 Genomes Project, http://www. internationalgenome.org). In the American subset populations (AMR) included in the 1000 Genomes Project (Mexican, Colombian, Peruvian and Dominicans), the allele $\mathrm{A}$ frequency is 0.0144 , similar to those found in the above mentioned populations. The absence/low frequency of the allele $\mathrm{A}$ in nonCaucasian populations have been attributed to an ancient founder effect, occurred after the divergence of Africans from non-Africans (14). On the other hand, its frequency was found between two to ten-fold increased in patients with idiopathic vein thrombosis compared to healthy control subjects (2). Thus, the absence of the allele A in this Venezuelan cohort prompted us to assess the probable F2 gene ethnic origin in the admixed Venezuelan populations.

\section{MATERIALS AND METHODS}

\section{Population}

A cohort of 160 healthy subjects (aged between 25 to 60 years old) from the metropolitan area of Caracas was selected. A $5 \mathrm{~mL}$ blood sample was withdrawn in 15\% EDTA$\mathrm{Na}_{4}$, and DNA was extracted as described elsewhere (13). The project was approved by the Bioethical Committee of the Venezuelan Institute for Scientific Research (IVIC). A signed informed consent was obtained from all participants.

Prothrombin polymorphism G20210A. Genotyping of the G20210A polymorphism (rs1799963) was performed by DNA PCR amplification followed by Hind III restriction endonuclease digestion, as previously described (13).

\section{F2 intragenic polymorphisms}

Three intragenic prothrombin (F2) polymorphisms: c. $240+83$ C $>\mathrm{T}$ (IVS 2; rs2070850), c.423-7 G>C (IVS 5; rs2070852) and c.1472+251 T>C (IVS 11; rs2282686), which have clearly different allelic frequencies in distinct ethnic groups were selected. Primers were designed with Primer-BLAST software (at https://www.ncbi.nlm.nih.gov/ tools/primer-blast/) and each SNP was detected by restriction analysis, as follow:

rs2070850 (C>T): (f) 5'-GAGAGTGCGTGGAGGAGAC and (r) 5'-CATGTCATGGAGCTGCACA, product size 286 bp. Allele $\mathrm{T}$ produces a recognition site for $\mathrm{BsmI}$ restriction enzyme.

rs2070852 (G>C): (f) 5'-CCACCATGGGCTGAGAAC and (r) 5'-CATTCGTGCCTCCTCACG, product size 195 bp. Allele $\mathrm{C}$ is recognized by the restriction endonuclease MnlI.

rs2282686 (T>C): (f) 5'- AAGAGCCCC TTTCCCTTTTC and (r) 5'- GGTGAAACCCA CCAGTCTCT, product size $266 \mathrm{bp}$. Allele T abolishes the restriction site for SmaI enzyme.

\section{Statistical analysis}

Allelic frequencies were calculated by direct counting. Hardy-Weinberg equilibrium was assessed for each SNP, using the $\chi^{2}$ test.

\section{RESULTS}

All the ancestors (up to two generations back) of the individuals recruited in the present study were born in Venezuela. The 160 individuals studied were homozygous for the wild type allele $\mathrm{G}$ of the prothrombin polymorphism G20210A.

The allele frequencies for the three SNPs are summarized in Table I. All of them were in Hardy-Weinberg equilibrium.

The allelic frequencies obtained for each polymorphism was compared to the five super-populations reported in the 1000 Genomes Project: Admixed American (AMR), European (EUR), African (AFR), South Asian (SAS) and East Asian (EAS) (Table I). 
TABLE I

ALLELIC FREQUENCIES OF THE THREE INTRAGENIC PROTHROMBIN (F2) POLYMORPHISMS IN DIFFERENT POPULATIONS.

\begin{tabular}{|c|c|c|c|}
\hline Populations & $\begin{array}{c}\text { rs2070850 } \\
\text { C }>\text { T } \\
\text { Ancestral allele: } \mathrm{C}\end{array}$ & $\begin{array}{c}\text { rs2070852 } \\
\text { G }>\mathrm{C} \\
\text { Ancestral allele: } \mathrm{G}\end{array}$ & $\begin{array}{c}\text { rs2282686 } \\
\mathrm{T}>\mathrm{C} \\
\text { Ancestral allele: } \mathrm{C}\end{array}$ \\
\hline VZL & $\begin{array}{l}\mathrm{C}=0.780 \\
\mathrm{~T}=0.220\end{array}$ & $\begin{array}{l}\mathrm{G}=0.439 \\
\mathrm{C}=0.561\end{array}$ & $\begin{aligned} T & =0.406 \\
C & =0.594\end{aligned}$ \\
\hline AMR & $\begin{aligned} \mathrm{C} & =0.718 \\
\mathrm{~T} & =0.282\end{aligned}$ & $\begin{array}{l}\mathrm{G}=0.416 \\
\mathrm{C}=0.584\end{array}$ & $\begin{array}{l}\mathrm{T}=0.590 \\
\mathrm{C}=0.409\end{array}$ \\
\hline EUR & $\begin{array}{l}\mathrm{C}=0.879 \\
\mathrm{~T}=0.121\end{array}$ & $\begin{array}{l}\mathrm{G}=0.292 \\
\mathrm{C}=0.708\end{array}$ & $\begin{array}{l}\mathrm{T}=0.709 \\
\mathrm{C}=0.290\end{array}$ \\
\hline AFR & $\begin{array}{l}\mathrm{C}=0.970 \\
\mathrm{~T}=0.030\end{array}$ & $\begin{array}{l}\mathrm{G}=0.873 \\
\mathrm{C}=0.126\end{array}$ & $\begin{array}{l}\mathrm{T}=0.210 \\
\mathrm{C}=0.790\end{array}$ \\
\hline SAS & $\begin{array}{l}\mathrm{C}=0.830 \\
\mathrm{~T}=0.170\end{array}$ & $\begin{array}{l}\mathrm{G}=0.293 \\
\mathrm{C}=0.706\end{array}$ & $\begin{array}{l}\mathrm{T}=0.707 \\
\mathrm{C}=0.292\end{array}$ \\
\hline EAS & $\begin{array}{l}\mathrm{C}=0.438 \\
\mathrm{~T}=0.562\end{array}$ & $\begin{array}{l}G=0.697 \\
C=0.303\end{array}$ & $\begin{aligned} \mathrm{T} & =0.301 \\
\mathrm{C} & =0.698\end{aligned}$ \\
\hline
\end{tabular}

VZL: Venezuelan (present study); AMR: Ameriean; EUR: European; AFR: African; SAS: South Asian; EAS: East Asian. Number of chromosomes in the Venezuelan sample: rs2070850 ( $\mathrm{n}=304)$; rs2070852 $(\mathrm{n}=312)$; rs2282686 $(\mathrm{n}=320)$.

Two of the three studied polymorphisms had intermediate frequencies for each allele, different from that of the main parental populations (European, African and Asian).

\section{DISCUSSION}

The prothrombin 20210G $>$ A transition (c. ${ }^{*} 97 \mathrm{G}>\mathrm{A}$, rs1799963), despite being located in the 3' untranslated region of the gene, has been associated with elevated plasma prothrombin levels that raises the risk of thrombotic events. The pathophysiologic mechanism of this genetic variation seems to be a gain-of-function mutation that produces an enhanced 3' end processing and increased mRNA accumulation, with the consequent increase in protein synthesis (15).

First reports of allelic frequencies showed that $18 \%$ of probands from thrombophilic families and $6 \%$ of nonrelated patients with deep vein thrombosis carried the allele A, contrasting with the lower frequencies in healthy controls (between 1 to $2 \%)(2,16)$.
Subsequent additional studies found that the allele $\mathrm{A}$ is almost absent in non Caucasoids populations. In the Venezuelan sample of 320 chromosomes of healthy individuals its frequency was null, even though at least one carrier is expected. This motivated us to assess the probable ethnic origin of the F2 gene, using population-specific intragenic polymorphic markers.

Venezuelan populations are the result of the genetic admixture of African, European and Amerindian ethnic groups (17). We chose three intragenic prothrombin (F2) polymorphisms: c. $240+83 \mathrm{C}>\mathrm{T}$ (IVS 2; rs2070850), 423-7 G>C (IVS 5; rs2070852) and c. $1472+251 \mathrm{~T}>\mathrm{C}$ (IVS 11; rs2282686), which have clearly different allelic frequencies between distinct ethnic groups.

It was not observed an allelic disequilibrium in the $F 2$ gene polymorphisms studied of the $F 2$ gene that allows to propose a greater similarity with a particular ethnic group, as have been reported for other populations (Table I), where one of the alleles 
have a higher frequency compared to other super-population samples.

The AMR population subgroup of 1000 Genomes Project was the exception, which showed greater similarity with the Venezuelan population. The individuals included in the AMR group belong to American admixed populations with the same parental origins as Venezuelan population (Spanish, Amerindian and African). Thus, the intermediate allelic frequencies observed in Venezuelans confirmed the mixed ethnic origin of our population, and the similar genetic background between the Ibero-American populations. The absence of $20210 \mathrm{~A}$ allele in the 320 chromosomes examined suggests that in this cohort, the Caucasian/Spanish contributions must be low, besides being a sample of healthy individuals, in whom the A allele should be less frequent.

In conclusion, a unique, discernible and/or probable ethnic origin of the $F 2$ gene in the very heterogeneous healthy population of the metropolitan area of Caracas (Capital District) cannot be established with the intragenic polymorphisms used, although a clearly admixed pattern of the population was supported.

\section{REFERENCES}

1. Soria JM, Almasy L, Souto JC, Tirado I, Borell M, Mateo J, Slifer S, Stone W, Blangero J, Fontcuberta J. Linkage analysis demonstrates that the prothrombin G20210A mutation jointly influences plasma prothrombin levels and risk of thrombosis. Blood 2000;95:2780-2785.

2. Poort SR, Rosendaal FR, Reitsma PH, Bertina RM. A common genetic variation in the 3'-untranslated region of the prothrombin gene is associated with elevated plasma prothrombin levels and an increase in venous thrombosis. Blood 1996; 88:3698-3703.

3. Ceelie H, Bertina RM, van Hylckama Vlieg A, Rosendaal FR, Vos HL. Polymorphisms in the prothrombin gene and their association with plasma prothrombin levels. Thromb Hemost 2001; 85:1066-1070.
4. Girolami A, Simioni P, Scarano L, Carraro G. Prothrombin and the prothrombin $20210 \mathrm{G}$ to A polymorphism: their relationship with hypercoagulability and thrombosis. Blood Reviews 1999; 13:205-210.

5. Mannucei PM. Laboratory detection of inherited thrombophilia: a historical perspective. Semin Thromb Hemost 2005; 31:5-10.

6. Martinelli I, Battaǵlioli T, Tosetto A, Legnani $\mathrm{C}$, Sottile $\mathrm{L}$, Ghiotto $\mathrm{R}$, Mannucei PM. Prothrombin A19911G polymorphism and the risk of venous thromboembolism. J Thromb Hemost 2006; 4:2582-2586.

7. Rosendaal F, Doggen C, Zivelin A, Arruda V, Aiach M, Siscovick D, Hillarp A, Watzke HH, Bernardi F, Cumming A, Preston F, Reitsma P. Geographic distribution of the $20210 \mathrm{G}$ to A prothrombin variant. Thromb Haemost 1998; 79:706-708.

8. Aznar J, Vayá A, Estellés A, Mira Y, Seguí R, Villa P, Ferrando F, Falcó C, Corella D, España F. Risk of venous thrombosis in carriers of the prothrombin G20210A variant and factor $\mathrm{V}$ Leiden and their interaction with oral contraceptives. Haematologica 2000; 85:1271-1276.

9. Burzotta F, Paciaroni K, De Stefano V, Chiusolo P, Manzoli A, Casorelli I, Leone AM, Rossi E, Leone G, Maseri A, Andreotti F. Increased prevalence of the G20210A prothrombin gene variant in acute coronary syndromes without metabolic or acquired risk factors or with limited extent of disease. Eur Heart J 2002; 23:26-30.

10. Reznikoff-Etiévan MF1, Cayol V, Carbonne B, Robert A, Coulet F, Milliez J. Factor V Leiden and G20210A prothrombin mutations are risk factors for very early recurrent miscarriage. BJOG 2001; 10812:12511254.

11. Tosetto A, Missiaglia E, Frezzato M, Rodeghiero F. The VITA project: prothrombin G20210A mutation and venous thromboembolism in the general population. Thromb Haemost 1999; 82:1395-1398.

12. Yapijakis C, Serefoglou Z, Nixon AM, Vylliotis A, Ragos V, Vairaktaris E. Prevalence of thrombosis-related DNA polymorphisms in a healthy Greek population. In Vivo 2012; 26:1095-1101.

13. Marchi R, Mareos L, Paradisi I. Comparison by sex between thrombin generation

Vol. 60(4): 269 - 274, 2019 
and fibrin network characteristics in a healthy population. Clin Chim Acta 2015; 441:86-89.

14. Zivelin A, Mor-Cohen R, Kovalsky V, Kornbrot N, Conard J, Peyvandi F, Kyrle PA, Bertina R, Peyvandi F, Emmerich J, Seligsohn U. Prothrombin $20210 \mathrm{G}>\mathrm{A}$ is an ancestral prothrombotic mutation that occurred in whites approximately 24,000 years aǵo. Blood 2006; 107: 4666-46689.

15. Gehring NH, Frede U, Neu-Yilik G, Hundsdoerfer P, Vetter B, Hentze MW, Kulozik AE. Increased efficiency of mRNA 3-prime end formation: a new genetic mechanism contributing to hereditary thrombophilia. Nature Genet 2001; 28: 389-392.

16. Franco RF, Trip MD, ten Cate H, van den Ende A, Prins MH, Kastelein JJ, Reitsma PH.The $20210 \mathrm{G}>\mathrm{A}$ mutation in the 3'-untranslated region of the prothrombin gene and the risk for arterial thrombotic disease. Br J Haematol 1999; 104:50-54.

17. Castro de Guerra D, Figuera Pérez C, Izaǵuirre MH, Arroyo Barahona E, Rodríguez-Larralde A, Vívenes de Lugo M. Gender differences in ancestral contribution and admixture in Venezuelan populations. Hum Biol 2011; 83:345-361. 